\title{
Success level of mangrove tree planting real in Kepulauan Meranti district, Riau, Indonesia
}

\begin{abstract}
The needs of the archipelagic community to the land for the cultivation of prawn, and materials for the needs of building materials and charcoal mangroves resulted in the large number of mangrove trees that have transition allotment, from conservation land in coastal areas to residential areas, harbors, aquaculture, production forest to be used as a means of life others. That is what is experienced by mangrove in District of Kepulauan Meranti, Riau, Indonesia. The specific objective of this research is to measure the success rate of mangrove tree planting and mangrove tree growth rate in Tebing Tinggi island, Meranti Islands District. The research design used is exploratory research with quantitative approach. The Mangroves Reforestation Program conducted by the Government of District of Kepulauan Meranti together with the community on 28 October 2015 ago. Type of mangrove planted is Rhizophora mucronata. Determination of samples of mangrove trees was taken from several land areas by the survey plots in 10 locations in Tebing Tinggi island, Meranti Islands. Each plot is $3 \times 3 \mathrm{~m}$. Data collected in this research are primary data that is the number of live trees, tree height, number of leaves, leaf length, and leaf width. Collection data using survey method. Primary data obtained from field surveys are presented in the form of frequency tables and descriptions. Furthermore, the data is processed and analyzed descriptively. The results show that the success rate of mangrove trees planting reached $72 \%$. This indicates that Rhizophora mucronata is an easy-living mangrove species in a wide range of habitats. Overall, the growth rate of mangrove trees shows good results, in terms of tree height, leaf number, leaf length, and leaf width.
\end{abstract}

Keywords: mangrove, growth, Tebing Tinggi island, Kepulauan Meranti District
Volume 7 Issue 4 - 2018

Kamaruddin Eddiwan, Sukendi

Environmental Science Program, Post Graduate University of Riau, Indonesia

Correspondence: Kamaruddin Eddiwan, Environmental Science Program, Post Graduate University of Riau, Campus Gobah, Jl. Patimura, Pekanbaru, Riau, Indonesia,

Email kamaruddineddiwan@gmail.com

Received: July 06, 2018 | Published: July 25, 2018

\section{Introduction}

Increasing the need for land for human life, resulting in many shifts in the designation of conservation land in the coastal areas into settlements, ports, aquaculture, and other means of life. No exception ecosystem of mangrove in the coastal area. According to, ${ }^{1}$ since the 1980 s when there was a blast of mangrove timber exports to Malaysia and Singapore, thousands of hectares of mangrove areas have been converted into production forest areas. Not to mention the utilization of mangrove for various human purposes, causing mangrove tree felling cannot be avoided. Thus the mangrove forests face many threats and damage that can lead to extinction. In fact, mangrove forest is an important ecosystem in coastal areas. Mangroves are plants that can live in areas of high salinity, but still need fresh water intake.

Many of the environmental services provided by mangrove forests include biota living habitats (such as crabs, shrimp, fish, and shellfish), spawning grounds, food providers for biota, area shielding from waves, climate effects locally and an absorber of carbon dioxide $\left(\mathrm{CO}_{2}\right)$. As we know the amount of carbon in the air atmosphere causes the greenhouse effect and global warming. There are still many services of mangrove forest given to mankind, such as economic function and also a social function. The benefits of mangrove forests are part of this paper.

With the change of designation, some mangrove ecosystems are damaged. For that, efforts should be made to replant mangrove trees as an effort to conserve coastal areas. Conservation activities are a shared responsibility between the government and the community, so the community should be involved intensively in the conservation of coastal and marine resources. Efforts to mitigate mangrove degradation have been done but the results have not been satisfactory. One way of mitigating mangrove degradation developed by Bosire et al., ${ }^{2}$ is the existence of 10 stages of activities in the prevention of mangrove degradation.

The stages are: 1) understanding the ecology of species and mangrove communities; 2) understanding the hydrological suitability and placement of the planting; 3 ) assess the factors that will hamper succession; 4) incorporating human factors i.e. surveys of the subsistence level (dependence) of users, traditions, perceptions, needs and alternatives of the community as an effort to sustain the utilization; 5) choosing the suitability of mangrove restoration sites; 6) preparation of hydrological enabling conditions and removal of inhibiting factors in natural regeneration; 7) if it fails in natural regeneration, then the suitability of species is selected, the population to be planted; 8) mangrove planting with human assistance; 9) assessment of the success rate of restoration implementation by monitoring and assessing: the potential for sustainable use, vegetation development and succession, the emergence of fauna, and environmental factors and processes; 10) recommendation. ${ }^{3}$

The Government of the District of Kepulauan Meranti together with people who have concern for mangrove damage at Tebing Tinggi island, Meranti Islands District, have re-planted mangrove trees on October 28, 2016, as many as 15,000 trees (Figure 1). The planting is based on consideration of the importance of mangrove ecosystem for coastal ecology and the surrounding environment. To monitor the conservation efforts of coastal areas, then measured the growth rate and success rate of mangrove trees to ensure that the trees grow well. In accordance with this, the writing of this article aims to measure: 1) the success rate of mangrove tree planting; 2) the growth rate of 
mangrove trees. Measuring the growth rate of mangrove is important to know because if the trees grow well and form mangrove forest vegetation, then this ecosystem will work very big for the life of living creature around it, like physical function, biology function, and chemical function.

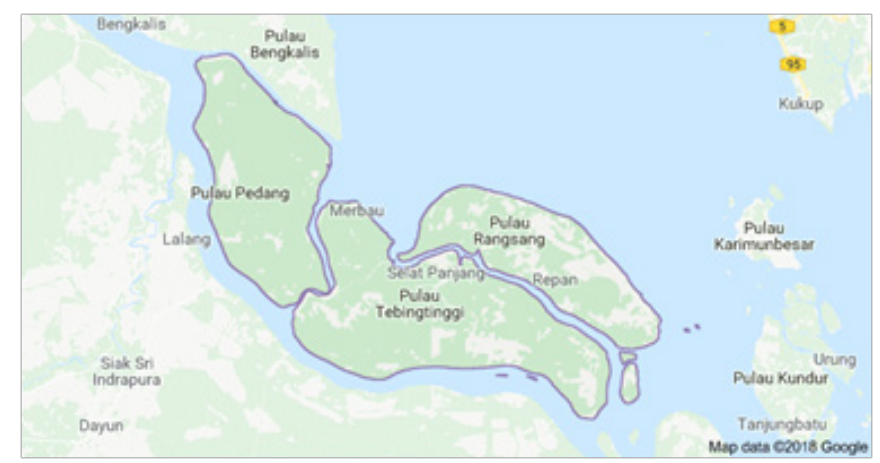

Figure I Map of Regency of Meranti Islands, ( ) showing location where to do mangrove planting activity.

\section{Materials and methods}

This research was conducted in June 2018, located on Tebing Tinggiisland, Meranti Islands, Riau with ordinate 0o 42'30 “; 10 28'0 "LU, and 1020 12'0"; 103o 10'0 "BT. The research design used is an exploratory research design, with a quantitative approach to measure the success rate of mangrove planting and its growth rate. The selected population is all mangrove trees that have been planted on Tebing Tinggi island, Meranti Islands district, Riau when the reforestation program has been implemented by the Government of Meranti

Archipelago district together with the community on October 28, 2015, ago. While the evaluation of growth rate of mangrove trees done in Tebing Tinggi island. The total number of mangrove trees as a whole is 5,000 trees. Type of mangrove trees that have been planted consists of Rhizophora mucronata and Rhizophora stylosa. Determination of samples of mangrove trees was taken from several land areas by making survey plots in 10 locations randomly on Tebing Tinggi island, and each plot has an area of $3 \times 3 \mathrm{~m} 2$. The data collected were primary data, i.e. tree height, number of live trees, number of leaves, leaf length, and leaf width. Primary data obtained from field surveys are presented in the form of frequency tables and descriptions. Furthermore, the data is processed and analyzed descriptively.

\section{Results and discussion}

\section{General condition of research sites}

Tebing Tinggi islandis located in the administrative area of District of Kepulauan Meranti. Meranti Islands District has an area of $3714.19 \mathrm{~km} 2(371,419 \mathrm{ha})$ and has a population of 182,152 people (Central Statistics Agency of District of Kepulauan Meranti, 2015). Selatpanjang city as the administrative Centre of District of Kepulauan Meranti, this island has available Regent office and other government facilities such as Community Health Center (PUSKESMAS), School, and homestay. To reach Tebing Tinggi island, Meranti Islands is not too difficult, because it can be through the dock Selatpanjang, Meranti Islands District. Because the distance is not too far from the Capital District and the villages in the District of Meranti Islands, many sea transport that stopover or special route only to and from this island. In addition to this island in the allotment for settlements, Tebing Tinggi island, Meranti Islands now transformed into a busy transit area. This island also saves a lot of tourism potential and natural resources such as fisheries and agriculture. To reach the island Tebing Tinggi can be reached within approximately 5(five) hours by using a speedboat or fast ferry from Pekanbaru (the capital of Riau province).

Mangrove planting activity is one of the reforestation program implemented by the Government of Meranti Archipelago District together with the community. This reforestation site was conducted in Tebing Tinggi island, Meranti Islands District, led by Head of Environmental Agency of District of Kepulauan Meranti. Mangrove seedlings planted on Tebing Tinggi island, amounting to 5,000 seedlings, consisting of 2(two) mangrove species namely Rhizophora mucronata as many as 3,000 seedlings and Rhizophora stylosa as many as 2,000 seedlings. Planting activities were conducted on October 28, 2015.

\section{Success rate of mangrove tree planting}

Measurement of the growth rate of mangrove trees is done through several indicators, namely: the number of live trees, tree height, and number of leaves, leaf length, and tree width. The observations on the 10 plots in the form of the average of each indicator are presented in Table 1.

Based on field measurements, the percentage of live trees on all plots is $72 \%$. This percentage is quite good because its percentage is close to $75 \%$ (Figure 2). This indicates that Rhizophora mucronata and Rhizophora stylosa are easy-living mangrove species in a wide range of habitats. Blasco explains that if the beach is calm and friendly, mangrove propagules can soon grow and enlarge so that mangroves are known as ecosystems capable of manipulating their own habitat.

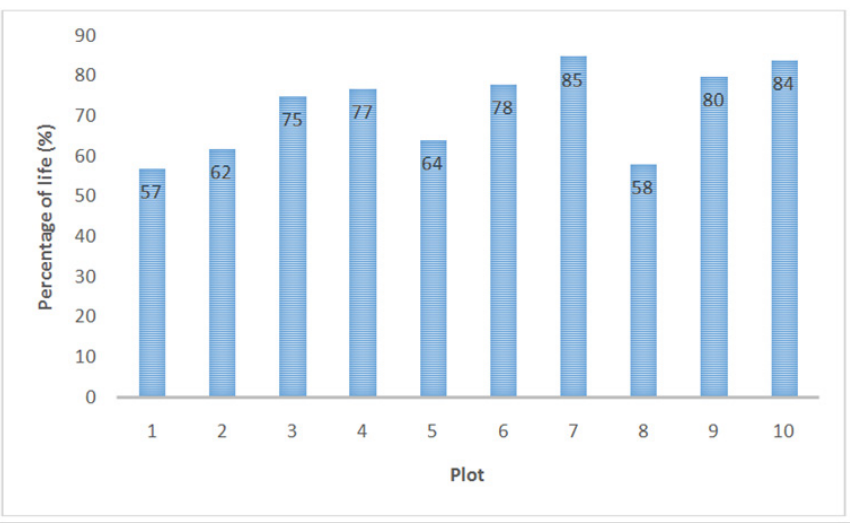

Figure 2 Percentage of mangrove tree life in each study plot.

In Figure 1 it can be seen that the best percentage of live mangrove trees is in plots 7 and 10 , i.e. $85 \%$ and $84 \%$, while the lowest percentage of life is in plot 1 is $57 \%$. This is caused by several factors, including the type of substrate, exposure to the waves, inundation by the tide. ${ }^{5}$ Mangrove vegetation usually prefers some muddy soil rich in organic matter. ${ }^{6}$ If the nutrients in organic materials are available in sufficient quantities, then the growth of mangrove vegetation will achieve optimum results. ${ }^{7}$ In plots 7 and 10, it is assumed that the availability of organic matter is high and the waves are small, so the percentage of the life of the mangrove tree is the highest.

Rhizophora mucronata is known as a mangrove plant that is able to adapt well to the basic properties of mangrove ecosystems. 
Nybakken, ${ }^{8}$ explains the basic properties of mangrove ecosystems include the high level of milling, low oxygen levels, high salinity (salinity content), and the influence of tidal water cycle. So this ecosystem is very extreme and very dynamic and including the most rapidly changing, especially in the outermost.

Facing variations of environmental conditions like this, naturally formed zonation of mangrove vegetation; which are usually layered from the outer part exposed to the ocean waves, to the relatively dry interior. The types of mangroves (Rhizophora spp.) Usually grow in the outer parts that are often battered by the waves. Mangrove Rhizophora apiculata and $R$. mucronata grow on mud land. While $R$. stylosa and clumps mangrove (Sonneratiaalba) grow on muddy sand. ${ }^{6}$ In the quieter parts of the outer zone or pioneer, zone live white flame trees (Avicenniaalba). ${ }^{9}$

In the deeper part, which is still inundated high tide, commonly encountered mixed mangrove $R$. mucronata. While near the riverbanks, more fresh water, commonly found Nipah (Nypafruticans), pidada (Sonneratiacaseolaris) and Bintaro (Cerbera spp.). In the drier parts of the interior, the forests are obtained Nirih (Xylocarpus spp.), Teruntum (Lumnitzera racemosa), Dungun (Heritiera littoralis) and blind wood (Excoecaria agallocha). Mangrove forests face many threats and damage that could bring extinction. ${ }^{10}$ The threat is caused either by natural causes or by humans. But the threat of human activities that have the greatest and most decisive impact on the sustainability of mangrove forests. ${ }^{8}$

\section{Growth rate of mangrove tree}

Tall Trees the height of mangrove trees at the time of planting ranges from $60-80 \mathrm{~cm}$. If the middle values are taken, then the height of the mangrove trees at the time of planting is $70 \mathrm{~cm}$. Based on the data in Table 1 it can be seen that the average tree height of all plots is $84.71 \mathrm{~cm}$. Means the mangrove tree for 1 year of planting gives the average height increase is $14,71 \mathrm{~cm}$. The growth rate of trees in each plot can be seen in Figure 3.

In Figure 3 it can be seen that the best average tree height is in plot $8(94 \mathrm{~cm})$, although the percentage of life is $59 \%$. Presumably, as the percentage of life is relatively low, the nutrients available on the substrate are utilized by a few trees and it gives the best height increase. The lowest average tree height is on plot $9(70,31 \mathrm{~cm})$ with a live percentage of $81 \%$. This means that trees on plot 9 give an average height of $0.31 \mathrm{~cm}$ for 1 year.

Table I Mangrove tree growth rates after one year of planting

\begin{tabular}{|c|c|c|c|c|c|c|c|c|c|c|c|}
\hline Variables & Blok-I & Blok-2 & Blok-3 & Blok-4 & Blok-5 & Blok-6 & Blok-7 & Blok-8 & Blok-9 & Blok-10 & average \\
\hline $\begin{array}{l}\text { Number } \\
\text { of live tree } \\
\text { trunks / } \\
\text { Number } \\
\text { of trees } \\
\text { planted }\end{array}$ & $18 / 32=0.56$ & $21 / 33=0.64$ & $26 / 35=0.74$ & $24 / 32=0.75$ & $23 / 35=0.66$ & $25 / 32=0.78$ & $27 / 32=0.84$ & $19 / 32=0.59$ & $26 / 32=0.81$ & $32 / 38=0.84$ & 0.72 \\
\hline High tree & $85.39 \pm 5.21$ & $91.14 \pm 4.82$ & $88.85 \pm 17.83$ & $79.42 \pm 4.75$ & $83.87 \pm 3.78$ & $85.84 \pm 4.00$ & $82.67 \pm 3.59$ & $94.00 \pm 3.87$ & $70.31 \pm 1.03$ & $85.63 \pm 4.29$ & 84.71 \\
\hline Mid & 83 & 93 & 86 & 73.5 & 86 & 84 & 88 & 95 & 78.5 & 95 & \\
\hline Min & 34 & 35 & 51 & 42 & 56 & 42 & 49 & 50 & 45 & 8 & \\
\hline Max & 114 & 124 & 119 & 126 & 119 & 115 & 110 & 120 & 100 & 117 & \\
\hline $\begin{array}{l}\text { Number of } \\
\text { leaves }\end{array}$ & $8.94 \pm 1.15$ & $11.10 \pm 1.42$ & $12.23 \pm 8.23$ & $13.00 \pm 1.54$ & $12.74 \pm 1.15$ & $8.72 \pm 1.08$ & $8.19 \pm 0.97$ & $7.68 \pm 0.88$ & $5.85 \pm 0.88$ & $8.38 \pm 0.92$ & 9.68 \\
\hline Mid & 7.5 & 9 & 9.5 & 11.5 & 11 & 8 & 8 & 6 & 4 & 6 & \\
\hline Min & 3 & 2 & 3 & 3 & 6 & 2 & 2 & 4 & 2 & 3 & \\
\hline $\operatorname{Max}$ & 19 & 27 & 36 & 33 & 25 & 24 & 24 & 19 & 24 & 24 & \\
\hline Leaf width & $3.24 \pm 0.19$ & $3.50 \pm 0.21$ & $4.90 \pm 1.84$ & $4.03 \pm 0.30$ & $4.87 \pm 0.37$ & $4.54 \pm 0.33$ & $4.31 \pm 0.29$ & $4.94 \pm 0.37$ & $3.70 \pm 0.30$ & $4.64 \pm 0.32$ & 4.27 \\
\hline Mid & 3 & 3 & 5 & 4 & 4 & 4 & 4 & 5 & 4 & 4 & \\
\hline Min & 1.5 & 1.5 & 2 & 2.5 & 2 & 2.5 & 2 & 3 & 2 & 2.5 & \\
\hline Max & 5 & 6 & 8 & 8 & 8 & 8 & 7 & 8 & 8 & 8 & \\
\hline Leaf length & $6.53 \pm 0.38$ & $7.05 \pm 0.34$ & $10.23 \pm 0.70$ & $8.97 \pm .51$ & $11.00 \pm 0.89$ & $10.52 \pm 0.80$ & $9.87 \pm 0.66$ & $11.38 \pm 0.86$ & $8.20 \pm 0.66$ & $10.24 \pm 0.66$ & 9.40 \\
\hline Mid & 6 & 7 & 9 & 8 & 10 & 10.5 & 10 & 10 & 8 & 9 & \\
\hline Min & 3 & 3 & 5 & 6 & 5 & 5 & 5 & 5 & 4 & 5 & \\
\hline $\operatorname{Max}$ & 9 & 10 & 18 & 15 & 19 & 19 & 17 & 17 & 17 & 18 & \\
\hline
\end{tabular}




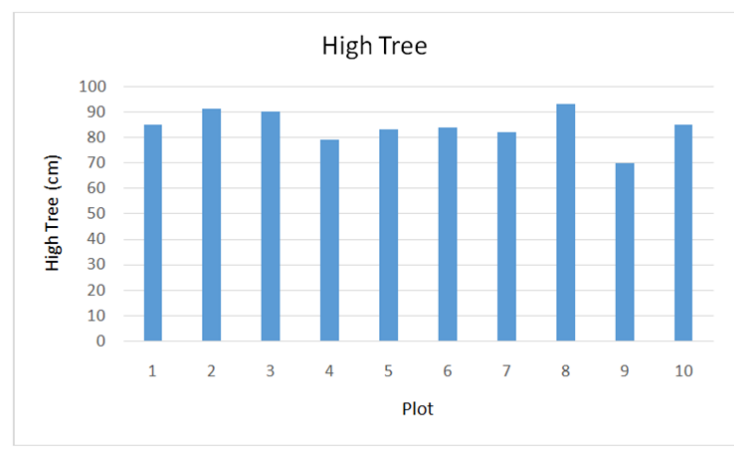

Figure 3 Average mangrove tree height in each study plot.

\section{Leaf amount}

The second indicator measured to analyze the mangrove growth rate is the number of leaves. Mangrove trees are plants that photosynthesis sunlight into food, so the number of leaves determines mangrove productivity in food production. ${ }^{4}$ Therefore, this study is done by counting the number of leaves. The average number of leaves at the study sites was 9.6810 (Table 2), while the mean number of leaves in each study plot is presented in Figure 4.

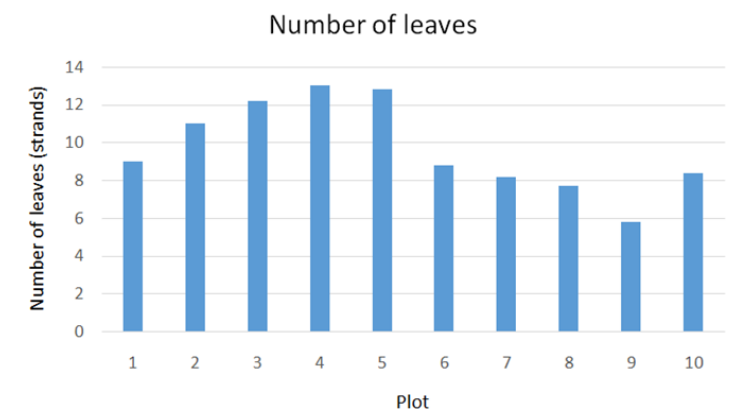

Figure 4 Average number of mangrove leaves in each research plot.

In Figure 4 it can be seen that the best average number of leaves is in plot 4 (13 pieces). The other plots have the number of leaves $<13$ pieces. The number of leaves of mangrove trees is important to note because these leaves serve as a place of photosynthesis. In addition, the leaves will later become litter that fell into the sediment and used by biota-biota as food. ${ }^{2}$ Litter of mangrove leaves that fall, some are used directly by the biota, and there is also a decomposed first by new organisms can be utilized by the biota.

Wu et al. ${ }^{11}$ explain that fish cultivation conducted on the mangrove ecosystem utilize litter of mangrove leaves as a feed. The existence of mangrove trees that have a positive impact in fishery business is the nitrogen content in the shrimp farming business which shows a positive effect of increasing the nitrogen concentration derived from leaf blur so that the real effect on the local environment. ${ }^{12}$

\section{Leaf width}

Leaf width is the third indicator measured to analyze mangrove growth rates. The fertility of mangrove trees that grow can be seen from the width of the leaves. The wider the leaves, the higher the growth rate of the tree. Su, et al., ${ }^{10}$ explains that mangrove vegetation will flourish in areas where there are puddling and accumulation of organic matter. Both in bays that are protected from the onslaught of the waves, or around the mouth of the river where water slows down and deposits the mud they transport from the upper reaches of the river. ${ }^{13}$ Therefore, mangrove is also known as the brackish forest or tidal forest The average leaf width at the study site was $4.27 \mathrm{~cm}$ (Table 1), while the average leaf width in each plot can be seen in Figure 5.

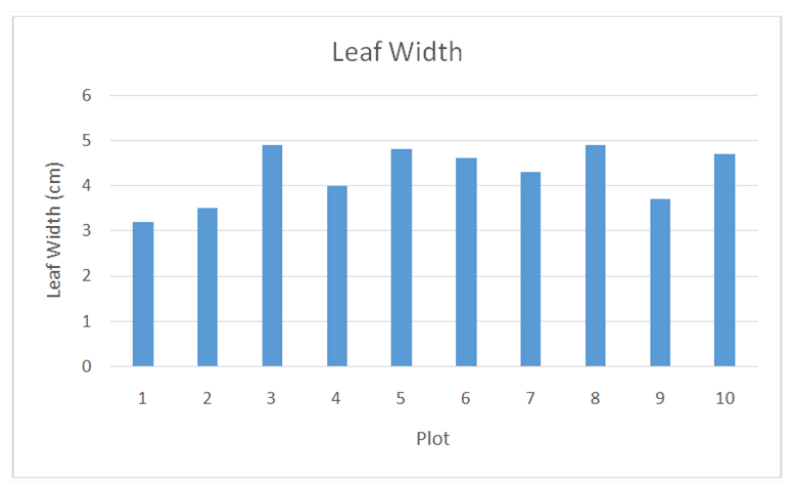

Figure 5 Average leaf width in each plot.

In Figure 4 it can be seen that the average leaf width is best in plot $8(4.94 \mathrm{~cm})$. In terms of the number of leaves, in plot 8 are relatively low, but the width of the leaves is highest among all plots. Suspected because of the number of leaves a little, then the best leaf fertility.

\section{Leaf length}

Leaf length is the fourth indicator measured to analyze mangrove growth rates. As well as leaf width, the length of leaves also determines the fertility of mangrove trees. The longer the leaves, the higher the growth rate of the tree. The average leaf length in all plots was $9.40 \mathrm{~cm}$ (Table 2), while the average leaf length in each plot is presented in Figure 6.

In Figure 6 it can be seen that the best average leaf length is in plot $8(11.38 \mathrm{~cm})$. Can be seen in Figure 5, that the best leaf width is in plot 4 , it turns out that mangrove trees in plot 4 do not automatically have the best leaf length. The length of the leaves in the plot is low, whereas the width of the leaves is the best. This suggests that the leaf size in the sampling plots has almost the same proportions.

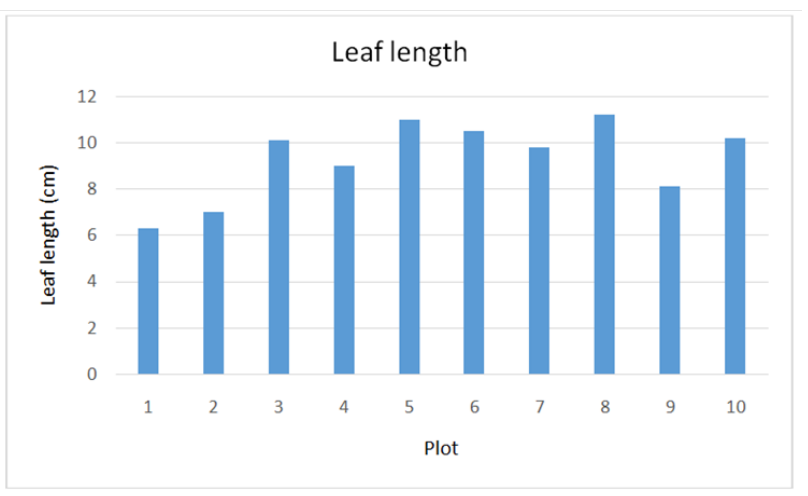

Figure 6 Average Leaf Length in Each Plot.

Overall, the growth rate of mangrove trees showed good results, in terms of tree height, leaf number, leaf length, and leaf width. It is expected that mangrove trees planted in Tebing Tinggi island, Meranti Islands can restore mangrove ecosystem damaged by human activities. 
According to,${ }^{14}$ mangroves grown on the edge of large rivers serve as the final shelter for waste from urban and upstream river-borne industries. Solid and liquid wastes dissolved in river water carried by streams into the mouths of rivers and open seas. ${ }^{15}$ The mangrove forest area will become a landfill area, especially if the pollutant entering the estuary environment exceeds the natural purification capability by water. ${ }^{16}$ Natural mangroves play an effective role in protecting the coast from natural stress and erosion. ${ }^{17}$ In a survey that has been done, found in mangrove ecosystems are scattered about solid waste such as plastic, cork, glass and cardboard that accumulate and caught in the roots of mangrove. ${ }^{18}$ Garbage disposal into this mangrove ecosystem is an indicator of the low concern and care of the community on the conservation of the aquatic environment. ${ }^{19}$

In addition, natural factors can cause damage to the mangrove ecosystem, such as the occurrence of a very large tidal wave (tsunami), and this is more dramatic and cannot be prevented by humans. On the other hand, human-induced damages such as uncontrolled mangrove use, clearing for farming without consideration of environmental sustainability, mangrove logging for mangrove charcoal and the need for excessive building materials. Damage caused by human actions is the most dominant and actually can be prevented, but it needs a new paradigm that is stronger and must involve various sectors (crosssectoral) in its handling. The preservation of the mangrove ecosystem is the responsibility of all parties.

According to ${ }^{20}$ community participation in mangrove forest management needs to be done through several strategies, among which are: (1) development of human resources quality through education and training activities and extension; (2) development of trench system (silvofishery); (3) institutional development through role involvement in the Mangrove Forest Farmer Group; and (4) development of compliance with the implementation of laws and regulations. In addition, it needs assistance to the community. ${ }^{21}$

According to, ${ }^{22}$ on the coast of South Sulawesi, the participation of farmer groups in mangrove management is crucial to the success of mangrove restoration. Communities are required to preserve mangroves, in return for ecological benefits such as coastal protection and preservation of fish biodiversity, as well as the direct economic benefits of Rhizophora timber and Rhizophora seedlings sold for the benefit of the restoration program..$^{23}$ One of the largest Rhizophora seedlings and breeding center'sin Indonesia is in Java. ${ }^{24}$

\section{Conclusion}

The success rate of mangrove trees planting reached $72 \%$. This percentage is quite good because the percentage is close to $75 \%$. This indicates that mangrove trees (Rhizophora mucronata) are easy-living mangrove species in a wide range of habitats. Habitat on Tebing Tinggi island, Meranti islands strongly support the life of mangrove trees.

Overall, the growth rate of mangrove trees showed good results, in terms of tree height, leaf number, leaf length, and leaf width. The height of mangrove trees at the time of planting ranges from $60-80 \mathrm{~cm}$. If the middle values are taken, then the height of the mangrove trees at the time of planting is $70 \mathrm{~cm}$. Currently, the average tree height of all plots is $84.71 \mathrm{~cm}$. Means the mangrove tree for 1 year of planting gives the average height increase is $14,71 \mathrm{~cm}$. The average number of leaves at the study location was 9.68-10sheets. The average leaf width at the study site was $4.27 \mathrm{~cm}$. The average leaf length in all plots is $9.40 \mathrm{~cm}$.

\section{Acknowledgements}

None.

\section{Conflict of interests}

Author declares that there is no conflict of interest.

\section{References}

1. Aheto DW, Stephen K, Isaac O, et al. Community-based mangrove forest management: Implications for local livelihoods and coastal resource conservation along the Volta estuary catchment area of Ghana. Ocean Coast Manag. 2016;127:43-54.

2. Bosire JO, Dahdouh FG, Walton M, et al. Functionality of restored mangroves: A review. Aquatic Botany. 2008;89(2):251-259.

3. Mitra A, Zaman S, Bhattacharyya SB. Heavy metal pollution in the lower gangetic mangrove ecosystem. Community, Environ. Disaster Risk Manag. 2013;13:97-113.

4. Blasco F. Climatic factors and the biology of mangrove plants, in The Mangrove Ecosystem: research methods. 1983; p.18-35.

5. Amri A. Community Participation in Rehabilitation, Con- Servation and Management of Mangroves: Lessons from Coastal Areas of South Sulawesi, Indonesia. African Study Monogr. 2005; 29:19-30.

6. Central Statistics Agency of District of Kepulauan Meranti. 2015. Statistical Report in the District of Kepulauan Meranti in Figures 2015. 2015 .

7. Alongi D. Paradigm shifts in mangrove biology, Coast. Wetl An Integr Ecosyst Approach. 2009; p. 615-640.

8. Nybakken JW, Marine Biology: An Ecological Approach, 4 edn. 2005.

9. Biswas H, Mukhopadhyay SK, Sen S, et al. Spatial and temporal patterns of methane dynamics in the tropical mangrove dominated estuary, NE coast of Bay of Bengal, India. J Mar Syst. 2007;68(1-2)55-64.

10. Abdullah NN. New trends in removing heavy metals from industrial wastewater. Procedia Environ Sci. 2014;3(1):1-9.

11. Clarke A, Johns L, Mangrove nurseries:Construction, propagation and planting, Fish Habitat Guidel. FHG. 2002; 32 p.

12. Fauzi A, Skidmore AK, van Gils H, et al. Shrimp pond effluent dominates foliar nitrogen in disturbed mangroves as mapped using hyperspectral imagery. Mar Pollut Bull. 2013;76(1-2):42-51.

13. Ferreira AC, Lacerda LD, Degradation and conservation of Brazilian mangroves, status and perspectives. Ocean Coast Manag. 2016;125:3846.

14. Field CB, Julie GO, Laura L Hoffman, et al. Mangrove Biodiversity and Ecosystem Function. Glob Ecol Biogeogr Lett. 1998;7(1):3.

15. Kaimuddin. Studi Kelembagaan Lokal Masyarakat dalam Pembangunan Hutan Mangrove di Desa Munte Kecamatan Bone-Bone (Kajian Base Line Kelembagaan Untuk Program Adaptasi Terhadap Perubahan Iklim Global). J Hutan dan Masy. III(1) 2008, p. 37-43, 2008.

16. Kathiresan K. Importance of Mangrove Ecosystem. Int J Mar Sci. 2012;2(10):70-89.

17. Kathiresan K, Bingham BL. Biology of mangroves and mangrove ecosystems. Adv Mar Biol. 2001;40:81-251.

18. Boyd RS. Heavy metal pollutants and chemical ecology: Exploring new frontiers. J Chem Ecol. 2010;36(1):46-58.

19. Tebing Tinggi Barat Island, Kepulauan Meranti District. Retrieved on February 11, 2015. 
20. Koh HL, De Angelis DL, Teh SY, Mangrove wetland ecosystem modeling in the everglades. Mangroves: Ecology, Biology and Taxonomy. 2011.

21. Kostermans AJGH, Sastroutomo SS, Regional Center for Tropical Biology (Bogor Indonesia), Symposium on Mangrove Forest Ecosystem Productivity in Southeast Asia, April 20-22, 1982, BIOTROP, Bogor, Indonesia: proceedings, 1982.
22. Kristensen E, Mangrove crabs as ecosystem engineers; with emphasis on sediment processes. J Sea Res. 2008;59(1-2):30-43.

23. Lakshmi K, Unni PN, Neelakandan N, et al. Environmental status of the mangrove ecosystem in Valapattanam river basin, Kerala. Ecol Environ Conserv. 2000;6(4):363-371.

24. Metras JN. Mangroves: Ecology, biology and taxonomy. 2011. 